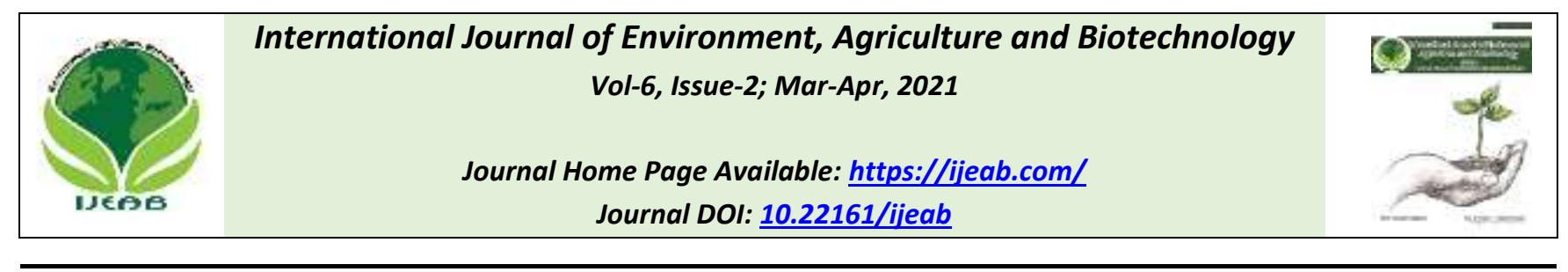

\title{
Optimized recombinant Bacillus Subtilis 168 whole-cell catalyzes one-step biosynthesis of high fructose syrup
}

\author{
Ildephonse Habimana ${ }^{1}$, Qiao Zhina ${ }^{1}$, Aqeel Sahibzada Muhammad ${ }^{2}$, Jean Damascene \\ Harindintwali ${ }^{1}$, Abdulqader Al-Adeeb ${ }^{1}$, Tolbert Osire ${ }^{1}$, Waleed AL-Ansi ${ }^{3,4}$, Mengkai \\ $\mathrm{Hu}^{1}$, Meijuan $\mathrm{Xu}^{1}$, Xian Zhang ${ }^{1}$, Zhiming Rao ${ }^{1, *}$
}

\begin{abstract}
${ }^{1}$ The Key Laboratory of Industrial Biotechnology, Ministry of Education, School of Biotechnology, Jiangnan University, $1800 \mathrm{LiHu}$ Boulevard,Wuxi 214122, Jiangsu, China

${ }^{2}$ National Engineering Laboratory for Cereal Fermentation Technology, Ministry of Education, School of Biotechnology, Jiangnan University, 1800 LiHu Boulevard, Wuxi 214122, Jiangsu, China

${ }^{3}$ School of Food Science and Technology, State Key Laboratory of Food Science and Technology, Jiangnan University, 1800 Lihu Avenue, Wuxi 214122, China.

${ }^{4}$ Department of Food Science and Technology, Faculty of Agriculture, Sana'a University, Sana'a, Yemen.

*Corresponding Author: Prof. Zhiming Rao
\end{abstract}

Received: 21 Nov 2020; Received in revised form: 11 Feb 2021; Accepted: 01 Mar 2021; Available online: 24 Mar 2021 (C)2021 The Author(s). Published by Infogain Publication. This is an open access article under the CC BY license (https://creativecommons.org/licenses/by/4.0/).

\begin{abstract}
High fructose syrup is a sweetener that can replace sucrose, which is widely used in the food and beverage industries. In this study, codon-optimized Actinoplanes missouriensis CICIM B0118 (A) derived glucose isomerase heterologous expression was realized in the food-grade strain Bacillus Subtilis 168, and the recombinant Bacillus Subtilis 168/pMA5-xylA was successfully constructed. The whole-cell bioconversion system of D-glucose isomerization to the biosynthesis of D-fructose was optimized. The results showed that the concentration of biocatalysts was DWC $40 \mathrm{~g} / \mathrm{L}$, and the concentration of substrate D-glucose was $180 \mathrm{~g} / \mathrm{L}, \mathrm{Mg} 2+$ concentration $10 \mathrm{mmol} / \mathrm{L}, \mathrm{Co} 2+$ concentration $1 \mathrm{mmol} / \mathrm{L}$, continuous conversion at $70^{\circ} \mathrm{C}, 220 \mathrm{R} / \mathrm{min}$ for $18 \mathrm{~h}, \mathrm{D}$-fructose concentration reached $103.32 \mathrm{~g} / \mathrm{L}$, the conversion rate was $57.4 \%$, realizing the high fructose syrup one-step safe biosynthesis. This research provided an experimental and theoretical basis for the industrialized and safe biosynthesis of high fructose syrup and had an important reference value.
\end{abstract}

Keywords-Glucose isomerase; isomerization; whole-cell catalysis; Bacillus Subtilis 168; high fructose syrup; biosynthesis.

\section{INTRODUCTION}

High Fructose Corn Syrup (HFCS), a purified, concentrated, an aqueous solution of functional saccharides currently used as a sugar substitute, is one of the most commonly used sweeteners in the production of nutritive beverages and foods, including soft drinks, ketchup, yogurts, ice-cream, chocolate milk, candies, jams, condiments, canned and packaged foods[1-3]. Besides, HFCS has been recently considered as a renewable resource for the production of 5-hydroxymethylfurfural and levulinic acid, which can be used in the synthesis of other valuable biopetrochemicals: plastics, green solvents, lubricants, and valuable biofuels[4-8]. The health benefits of HFS intake have been proven by insulin-independent metabolism, increased absorption of iron and zinc, enhanced ethanol metabolism, low-sugar and low-calorie contents, and desirable organoleptic properties [2,9]. Other advantages of HFS compared with other types of sugars include high sweetness, high solubility, and low viscosity, flavor enhancement, good humectant, does not cause any side effects in acidic foods and doesn't form crystals[3,9,10]. 
According to the fructose content, HFCS can be divided into three types HFS-42, HFS-55, and HFS-90. However, due to the low fructose content of HFS-42, the medical and health care value cannot be brought into full play, and it is easy to crystallize and precipitate during low-temperature storage and transportation, so HFS-55 with higher fructose concentration has become the mainstream product[1,2].The production methods of HFCS include chemical catalysis and enzymatic biocatalysis. The chemical catalytic method is that glucose is isomerized or acid hydrolyzed to fructose in an alkaline environment[2].

For more than a century, people have known that glucose can isomerize fructose through alkaline isomerization or acid hydrolysis. Therefore, this is a harsh process that leads to unacceptable sugar breakdown. Besides, the chemical synthesis of HFCS involves high calcination temperature and is not environmentally friendly[11-13]. The homogeneous Lewis acid generally has the problem of separation and recovery, and the synthesis of $\mathrm{Sn}-\beta$ zeolite is more complicated. On the other hand, Brønsted bases such as sodium hydroxide can also effectively isomerize glucose to fructose. In contrast, due to the severe degradation of fructose and glucose, they usually obtain a lower yield of glucose to fructose, and they also face the problem of separation and recovery $[4,12,14]$.

Owing to the aforementioned drawbacks of environmentally unfriendly chemical synthesis, commercial HFCS has been mainly produced by microbial synthesis since the early 1970s after Yoshiyuki Takasaki discovered a thermo-stable glucose isomerase (GIase) enzyme from yeast [15]. GIase, also known as D-xylose isomerase, is a widely used enzyme for the production of HFCS. It catalyzes not only the conversion of D-glucose to D-fructose but also the conversion of D-xylose to Dxylulose [16]. With increasing HFCS consumption, the production level of GIase has drawn extensive attention in recent years. Many microbial strains, including Streptomyces sp. $\quad$ CH7[17], Lactobacillus bifermentans[18], Bacillus coagulans [19], Streptomyces murinus, Hyperthermophilic Thermotoga [20], and Pseudomonas hydrophila [21], have been reported to produce glucose isomerase. Because of the increased global demand for HFCS, the level of Glase production has gained considerable attention, especially in the food and beverages industry. Due to the low productivity and stability of enzymes produced by wild-type microorganisms under harsh conditions, a more efficient expression system is needed for the production of recombinant GIase with desired properties for large-scale production of HFCS.

To obtain an effective expression mechanism, GIase has been heterologously expressed in a variety of hosts[22,23], ISSN: 2456-1878 and a variety of fermentation techniques, including fedbatch and high-density fermentation, have been used. As a result, GIase expression has greatly improved; for example, Akdag et al.[24] announced that using a beet molasses-based feeding method, they achieved the highest recombinant GIase production, $35.3 \mathrm{U} / \mathrm{mL}$, in E. coli. Due to its well-known genetics' history, short generation time, and suitability for low-cost high-density fermentation, E.coli is a common heterologous host for the expression of recombinant proteins[25]. However, improvements in GIase production, specially concerning HFCS-55 manufacturing, are still valued for industrial applications.

Although one-step biosynthesis of HFS-55 has achieved certain results, most of its host strains previously investigated with higher potential yields are Escherichia coli BL21, but in the catalytic process, BL21 may bring harmful toxin that do not meet the requirements of food safety into the target products[26-28]. Therefore, it is very meaningful to realize the heterologous expression of glucose isomerase in food safety strains with clear research background and to safely synthesize HFS-55 high fructose syrup in one step.

However, food safety requires a thorough investigation of food-grade microorganisms. Bacillus subtilis 168 and some other non-pathogenic related Bacillus species, which are free of exotoxins and endotoxins, and have a recognized history of safe use in foods are very useful for fermentation and large-scale cultivation[29].

Thus, an efficient expression of recombinant GIase in a generally regarded safe strain is necessary for improved economic HFCS-55 manufacturing and can contribute more to food security. In this study, a bacterial strain Bacillus Subtilis 168 was used as the host cell to heterologously express the glucose isomerase from $A$. missouriensis CICIM B0118 (A). The recombinant Bacillus Subtilis 168/pMA5-xylA was constructed. Using recombinant Bacillus Subtilis 168 as a whole-cell catalyst, the whole-cell catalytic conditions for isomerization of Dglucose to D-fructose were optimized. Under the optimal transformation system, HFS-55 high fructose syrup was synthesized safely in one step.

\section{MATERIALS AND METHODS}

\subsection{STRAIN AND PLASMID}

E. coli JM109, Bacillus Subtilis 168, and plasmid pMA5 were all preserved in our laboratory stock. The recombinant plasmid pET28a-xylA(genebank accession number: FJ858195.1) was synthesized by Suzhou Jinweizhi Biotechnology Co., Ltd. 


\subsection{EXPERIMENTAL REAGENTS}

Restriction enzyme NdeI and MluI, high fidelity enzyme, and homologous recombination enzyme cloning kit were purchased from Takara company. Small Plasmid Extraction Kit, agarose gel DNA recovery kit, and so on are purchased from Shanghai Jarry Bioengineering Co., Ltd., chloramphenicol, isopropyl - $\beta$-D- IPTG are purchased from Shanghai Bioengineering (Shanghai) Limited by Share Ltd, D- glucose is purchased from Mclean, D- fructose is purchased from Aladdin, glycerol, imidazole, sodium chloride and so on are all commercially analytical grades.

\subsection{CULTURE MEDIUM AND CONDITIONS}

LB medium: yeast extract $5 \mathrm{~g} / \mathrm{L}$, tryptone $10 \mathrm{~g} / \mathrm{L}$, sodium chloride $10 \mathrm{~g} / \mathrm{L}$ (solid medium with $1.5 \%$ agar powder) for $E$. coli culture. The culture temperature was $37^{\circ} \mathrm{C}$. TB medium: (12 g tryptone, $24 \mathrm{~g}$ yeast extract, 4 $\mathrm{ml}$ glycerol, $125.5 \mathrm{~g} \mathrm{~K}_{2} \mathrm{HPO}_{4}, 23 \mathrm{~g} \mathrm{KH}_{2} \mathrm{PO}_{4}$ ) per liter used for B.subtilis 168 culture. The culture temperature was $30^{\circ}$ C.

\subsection{METHODS}

\subsubsection{CONSTRUCTION OF THE RECOMBINANT STRAIN}

\subsubsection{CONSTRUCTION OF RECOMBINANT $E$. COLI JM109/PMA5-XYLA}

The recombinant plasmids pET28a-xylA and -xylAF: ttattcagatgaaaacatatg atgagtgttcaagccacccg(NdeI) , and xylA-R: atttcgacctctagaacgcgt ttagcgcgcacccagc(MluI) were used as plasmid template and primers respectively for PCR amplification. After ligation, the conjugated products were transformed into E. coli JM109 competent cells for cloning purpose, coated with LB plate containing $50 \mu \mathrm{g} /$ $\mathrm{mL}$ Kanamycin, and cultured overnight at $37^{\circ} \mathrm{C}$ incubator. The transformants were selected for colony PCR verification. The correct transformants were cultured in $10 \mathrm{ml}$ liquid containing $50 \mu \mathrm{g} / \mathrm{mL}$ Kanamycin for 8-12 $\mathrm{h}$ at $37^{\circ} \mathrm{C}$ and $180 \mathrm{R} / \mathrm{min}$. Then, the strains were preserved and the recombinant plasmids were extracted. The extracted recombinant plasmids were sent to Suzhou Jinweizhi Biotechnology Co Ltd, for sequencing analysis. The sequencing results were analyzed by snap gene software, and the correct strain was named E. coli JM109 / pMA5- xylA, harboring the recombinant plasmid pMA5xylA.

\subsubsection{CONSTRUCTION OF RECOMBINANT BACILLUS SUBTILIS 168/PMA5-XYLA.}

The recombinant plasmid pMA5-xylA was electroporated into Bacillus Subtilis 168 competent cells, coated on LB solid plate containing $50 \mu \mathrm{g} / \mathrm{mL}$ Kanamycin, and cultured upside down in a $37^{\circ} \mathrm{C}$ incubator overnight. The correct recombinant strains were named Bacillus Subtilis 168/pMA5-xylA

\subsection{EXPRESSION OF GLUCOSE ISOMERASE (GI)}

The preserved recombinant Bacillus Subtilis 168/pMA5xylA was activated on LB plate containing $50 \mu \mathrm{g} / \mathrm{mL}$ Kanamycin. The single colony was transferred to a $10 \mathrm{~mL}$ TB liquid medium (containing $50 \mu \mathrm{g} / \mathrm{mL}$ kanamycin) and cultured at $30^{\circ} \mathrm{C}$ and $200 \mathrm{rpm}$ for $12-24 \mathrm{~h}$. Then, the $50 \mathrm{ml}$ TB liquid medium (containing $50 \mu \mathrm{g} / \mathrm{mL}$ kanamycin) was transferred to a $1 \%$ inoculation amount and cultured at $30^{\circ} \mathrm{C}$ and $200 \mathrm{rpm}$ for 3-4 h. IPTG was added and cultured in a $30^{\circ} \mathrm{C}$ shaker for $12 \mathrm{~h}$. The cells were centrifuged at $4^{\circ} \mathrm{C}$ and $10000 \mathrm{rpm}$ for $10 \mathrm{~min}$. The cells were washed twice with PBS (pH 7.4, concentration $50 \mathrm{mmol} / \mathrm{L}$ ) buffer and then suspended. After adding the appropriate amount of lysozyme, the cells were placed on ice for $2 \sim 3 \mathrm{~h}$. The cells were broken by an ultrasonic crusher. The resultant solution was centrifuged for $20 \mathrm{~min}$ at $4{ }^{\circ} \mathrm{C}$ and $12000 \mathrm{R} / \mathrm{min}$. The supernatant was used for SDS-PAGE analysis.

\subsection{THE WHOLE-CELL CATALYTIC ACTIVITY OF RECOMBINANT BACILLUS SUBTILIS 168}

Reaction system[30] (25 ml): $2.5 \mathrm{ml} 8 \mathrm{mM} \mathrm{MgCl} 2,2.5 \mathrm{ml}$ $200 \mu \mathrm{mol} / \mathrm{L} \mathrm{CoCl}_{2}, 12.5 \mathrm{ml}, 2 \mathrm{~mol} / \mathrm{L}$ D-glucose and $1 \mathrm{~g}$ recombinant Bacillus Subtilis 168. The reaction was incubated at $70^{\circ} \mathrm{C}$ for $1 \mathrm{~h}$ and stopped ice bath for $5 \mathrm{~min}$. The supernatant was centrifuged and analyzed by HPLC. The HPLC conditions were: RID differential detector, Hiplex-Ca $(300 \mathrm{~mm} \times 7.7 \mathrm{~mm})$ column, ultrapure water as mobile phase, the flow rate of $0.6 \mathrm{ml} / \mathrm{min}$, column temperature of $80^{\circ} \mathrm{C}$, injection volume of $10 \mu \mathrm{L}$, detection wavelength of $210 \mathrm{~nm}$.

\subsection{OPTIMIZATION OF WHOLE-CELL CATALYSIS CONDITIONS}

\subsubsection{EFFECT OF CELL CONCENTRATION ON WHOLE-CELL CATALYTIC SYSTEM}

Under the conditions of substrate D-glucose concentration of $1 \mathrm{~mol} / \mathrm{L}, \mathrm{pH} 7.0, \mathrm{Mg}^{2+}$ concentration of $10 \mathrm{mmol} / \mathrm{L}$, $\mathrm{Co}^{2+}$ concentration of $1 \mathrm{mmol} / \mathrm{L}$, DCW of 20, 30, 40, 50, and $60 \mathrm{~g} / \mathrm{L}$, respectively, the reaction time was $1 \mathrm{~h}$ at $70^{\circ}$ $\mathrm{C}$, and the D-fructose content in the transformation solution was detected by HPLC to determine the optimal bacterial concentration.

\subsubsection{EFFECT OF METAL IONS ON WHOLE-CELL CATALYTIC SYSTEM}

Under the conditions of cell concentration $40 \mathrm{~g} / \mathrm{L}$, substrate D-glucose concentration $1 \mathrm{~mol} / \mathrm{L}, \mathrm{pH}$ 7.0, different metal ions $\mathrm{Ba}^{2+}(1 \mathrm{mmol} / \mathrm{L}), \mathrm{Cu}^{2+}(1 \mathrm{mmol} / \mathrm{L})$, $\mathrm{Fe}^{2+}(1 \mathrm{mmol} / \mathrm{L}), \mathrm{Mg}^{2+}(10 \mathrm{mmol} / \mathrm{L}), \mathrm{Ca}^{2+}(1 \mathrm{mmol} / \mathrm{L})$, $\mathrm{Mn}^{2+}(1 \mathrm{mmol} / \mathrm{L}), \mathrm{Co}^{2+}(1 \mathrm{mmol} / \mathrm{L})$ and $\mathrm{Zn}^{2+}(1 \mathrm{mmol} /$ 
L) were added respectively, and the reaction time was $1 \mathrm{~h}$ at $70^{\circ} \mathrm{C}$. The content of D-fructose in the conversion solution was determined by HPLC.

\subsubsection{EFFECT OF SUBSTRATE D-GLUCOSE CONCENTRATION ON WHOLE-CELL CATALYTIC SYSTEM}

Under the conditions of DCW $40 \mathrm{~g} / \mathrm{L}, \mathrm{pH} 7.0, \mathrm{Mg}^{2+} 10$ mmol / $\mathrm{L}$ and $\mathrm{Co}^{2+} 1 \mathrm{mmol} / \mathrm{L}$, the concentration of substrate D-glucose in the whole-cell transformation system was controlled to be $0.5 \mathrm{~mol} / \mathrm{L}, 1.0 \mathrm{~mol} / \mathrm{L}, 1.5$ $\mathrm{mol} / \mathrm{L}$ and $2.0 \mathrm{~mol} / \mathrm{L}$, and the reaction time was $1 \mathrm{~h}$ at $70{ }^{\circ} \mathrm{C}$. The content of $\mathrm{D}$-fructose in the transformation solution was determined by HPLC.

\subsubsection{EFFECT OF PH ON WHOLE-CELL CATALYTIC SYSTEM}

Under the conditions of cell concentration DCW $40 \mathrm{~g} / \mathrm{L}$, substrate D-glucose $1 \mathrm{~mol} / \mathrm{L}, \mathrm{Mg}^{2+} 10 \mathrm{mmol} / \mathrm{L}^{2}$ and $\mathrm{Co}^{2+}$ $1 \mathrm{mmol} / \mathrm{L}$, the reaction was carried out at $\mathrm{pH} 4.0-10.0$ (interval 1.0) and $70^{\circ} \mathrm{C}$ for $1 \mathrm{~h}$ respectively. The content of D-fructose in the conversion solution was determined by HPLC to determine the optimal reaction $\mathrm{pH}$. The buffer solutions included acetic acid sodium acetate buffer with $\mathrm{pH} 4.0,5.0$, and 6.0, Tris-HCl buffer with $\mathrm{pH} 7.0$ and 8.0, glycine $\mathrm{NaOH}$ buffer with $\mathrm{pH} 9.0$ and 10.0, and the concentrations were all $50 \mathrm{mmol} / \mathrm{L}$.

\subsubsection{EFFECT OF REACTION TEMPERATURE ON WHOLE-CELL CATAL YTIC SYSTEM}

Under the conditions of cell concentration DCW $40 \mathrm{~g} / \mathrm{L}$, substrate D-glucose $1 \mathrm{~mol} / \mathrm{L}, \mathrm{pH} 7.0, \mathrm{Mg}^{2+} 10 \mathrm{mmol} / \mathrm{L}$ and $\mathrm{Co}^{2+} 1 \mathrm{mmol} / \mathrm{L}$, the whole-cell catalytic system was placed in a constant temperature water bath at 40, 50, 60, 70 and $80^{\circ} \mathrm{C}$ for $1 \mathrm{~h}$ and the $\mathrm{D}$-fructose content in the conversion solution was detected by HPLC to determine the optimal reaction temperature.

\subsection{WHOLE-CELL BIOCATALYTIC BIOSYNTHESIS OF HIGH FRUCTOSE SYRUP}

The preserved recombinant Bacillus Subtilis 168/pMA5xylA was activated on an LB plate containing $50 \mu \mathrm{g} / \mathrm{ml}$ kanamycin. The single colony was transferred to $10 \mathrm{ml}$ TB liquid medium (containing $50 \mu \mathrm{g} / \mathrm{mL}$ kanamycin) for 12 $\mathrm{h}$ at $37^{\circ} \mathrm{C}$ and $200 \mathrm{rpm} / \mathrm{min}$, and then transferred to 200 $\mathrm{ml}$ TB liquid medium (containing $50 \mu \mathrm{g} / \mathrm{mL}$ kanamycin) at $1 \%$ inoculum for $3-4 \mathrm{~h}$ at $37^{\circ} \mathrm{C}$ and $200 \mathrm{rpm} / \mathrm{min}$. IPTG was added and cultured in a $30^{\circ} \mathrm{C}$ shaker for $12 \mathrm{~h}$. After centrifugation for $10 \mathrm{~min}$ at $4^{\circ} \mathrm{C}$ and $10000 \mathrm{rpm} / \mathrm{min}$, the cells were collected and used as the whole-cell biocatalysts.

Under the optimal conditions of whole-cell transformation (cell concentration DCW $40 \mathrm{~g} / \mathrm{L}$, substrate D-glucose concentration $1 \mathrm{~mol} / \mathrm{L}, \mathrm{pH} 8.0, \mathrm{Mg}^{2+}$ concentration 10 $\mathrm{mmol} / \mathrm{L}, \mathrm{Co}^{2+}$ concentration $1 \mathrm{mmol} / \mathrm{L}$ ), the reaction was carried out on a magnetic stirrer at $70^{\circ} \mathrm{C}$ and $220 \mathrm{rpm}$ for $18 \mathrm{~h} .1 \mathrm{ml}$ sample was collected every $3 \mathrm{~h}$, centrifuged at 4 ${ }^{\circ} \mathrm{C}$ and $12000 \mathrm{R} / \mathrm{min}$ for $15 \mathrm{~min}$, and the supernatant was analyzed by HPLC to detect the content of D-fructose.

\section{RESULTS AND DISCUSSION}

\subsection{CLONING AND EXPRESSION OF XYLA GENE ENCODING GLUCOSE ISOMERASE}

The gene sequence of glucose isomerase from $A$. missouriensis CICIM B0118 (A) was retrieved from the NCBI database [31], with a length of $1185 \mathrm{bp}$, which was submitted to Suzhou Jinweizhi Biotechnology Co Ltd for artificial synthesis, and the recombinant plasmid pET28axylA was obtained. The plasmid was used as a template for PCR amplification. The electrophoretic results are shown in Figure 1a. The specific bands (Lane 1 and 2 in Figure 1a) are consistent with the target. The recombinant E. coli JM109 / pMA5 -xylA was constructed by transferring the ligation product into E. coli JM109 competent cells. The recombinant plasmid pMA5-xylA obtained from the culture of recombinant $E$. coli JM109/pMA5-xylA was transferred into Bacillus subtilis 168 to construct recombinant Bacillus subtilis 168/pMA5xylA. The expression of GI was induced by IPTG and analyzed by SDS-PAGE. The results are shown in Fig. 1b. It can be seen from Lane 2 and 3 in the figure that the recombinant strain Bacillus subtilis 168/pMA5-xylA has an obvious protein expression band at the molecular weight of $43 \mathrm{kDa}$ as reported previously[30], that is, GI was successfully expressed in Bacillus subtilis 168 .

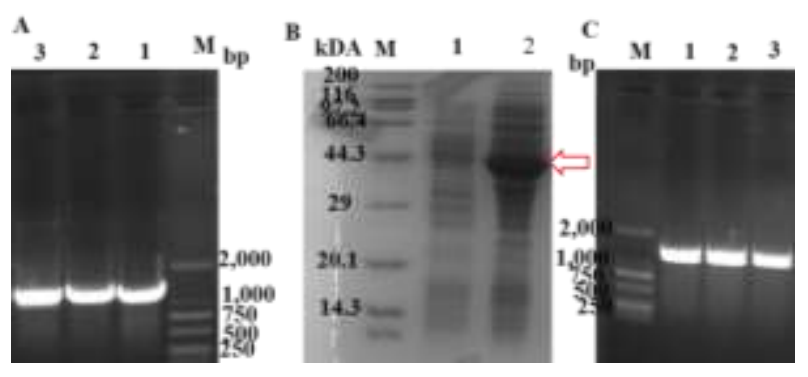

Fig. 1 Gene cloning and expression analysis of GI

Fig. A: PCR amplification of xylA gene, M: 2,000 BP nucleic acid marker; Fig. B: heterologous expression of glucose isomerase (GI), M: protein marker, lane 1: B.subtilis 168 wild type broken cells supernatant, lane 2: B.subtilis 168/pMA5-xylA broken cells supernatant; Fig. C: M:2,000 BP nucleic acid marker , lane 1,2,\& 3:B.subtilis 168/pMA5-xylA transformant colony PCR verification results. 


\subsection{WHOLE-CELL CATALYTIC PERFORMANCE TEST}

Using whole-cell as a catalyst has gradually replaced crude enzyme or pure enzyme in the biosynthesis of target products because cells can protect the enzyme from the adverse environment and shear force, and batch conversion can be repeated, and no cofactor or coenzyme need to be added to the reaction process[32]. Therefore, the whole cell of Bacillus subtilis 168 will be used as a catalyst for D-glucose isomerization to synthesize D-fructose.

Firstly, the whole-cell catalytic performance of recombinant Bacillus subtilis 168 was tested to see whether it can isomerize D-glucose to D-fructose. Results as shown in Figure 2, the whole-cell biocatalyst of Bacillus subtilis 168 could isomerize D-glucose to produce Dfructose. In the figure, the peak time of D-glucose and Dfructose was $17.106 \mathrm{~min}$ and $21.380 \mathrm{~min}$ respectively, which indicated that Bacillus subtilis 168 had the potential to produce high fructose syrup. The next step is to optimize the whole-cell catalytic system of D-glucose isomerization to D-fructose, and explore the effects of cell concentration, divalent metal ions, substrate D-glucose concentration, reaction $\mathrm{pH}$, and reaction temperature on $\mathrm{D}$ fructose synthesis.

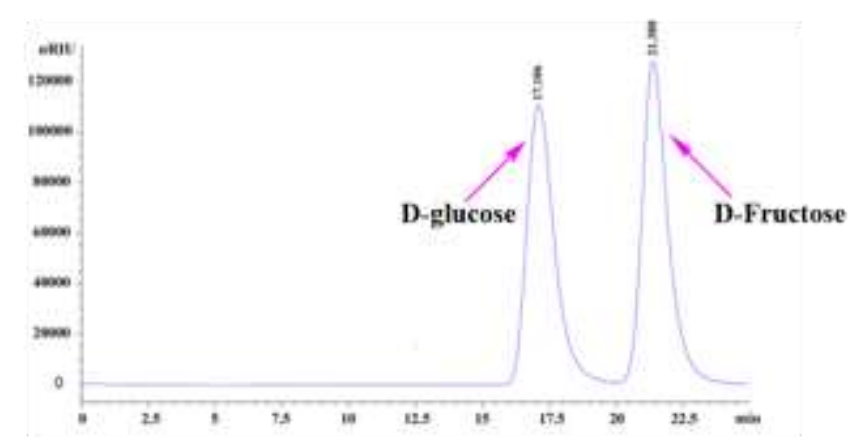

Fig. 2 HPLC detection results of the conversion solution

\subsection{OPTIMIZATION OF WHOLE-CELL CATALYSIS CONDITIONS}

\subsubsection{EFFECT OF CELL CONCENTRATION ON BI OTRANSFORMATION OF D-GLUCOSE TO D- FRUCTOSE}

The cell concentration reflects the content of glucose isomerase GI in the conversion system to a certain extent. Therefore, the different cell concentrations may affect the catalytic process of D-glucose isomerization to Dfructose, as shown in Figure 2. With the increase of cell concentration, D-fructose content increased; when cell concentration exceeded $40 \mathrm{~g} / \mathrm{L}$, although substrate concentration increased, D-fructose content decreased. When the cell concentration DCW was $40 \mathrm{~g} / \mathrm{L}$, the D- fructose content was the highest, which was $3.1 \mathrm{~g} / \mathrm{L}$. the optimal cell concentration for whole-cell catalytic synthesis of D-fructose was $40 \mathrm{~g} / \mathrm{L}$.

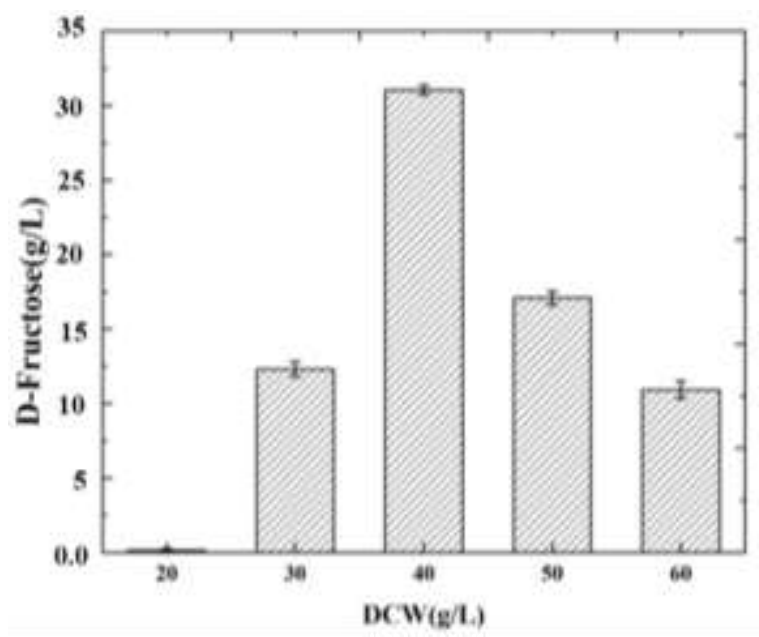

Fig. 3 The effect of cell concentration on D-glucose biotransformation to D-fructose

\subsubsection{EFFECTS OF DIVALENT METAL IONS ON BIOTRANSFORMATION OF D-GLUCOSE TO D- FRUCTOSE}

GI is a metal enzyme, combined with divalent metal ions, in the process of D-glucose biotransformation to Dfructose, metal ions are needed to assist the isomerization reaction, and divalent metal ions are very important for the activity and stability of GI [25]Different GI needs different divalent metal ions. Most of the reported GI mainly use $\mathrm{Mg}^{2+}, \mathrm{Mn}^{2+}, \mathrm{Co}^{2+}$ [33], or two metal ions as auxiliary catalysts [24,33].

Different divalent metal ions may have different effects on the catalytic process of D-glucose isomerization to Dfructose. Therefore, the effects of different divalent metal ions $\mathrm{Ba}^{2+}(1 \mathrm{~mm}), \mathrm{Cu}^{2+}(1 \mathrm{~mm}), \mathrm{Fe}^{2+}(1 \mathrm{~mm}), \mathrm{Mg}^{2+}(10$ $\mathrm{mm}), \mathrm{Ca}^{2+}(1 \mathrm{~mm}), \mathrm{Mn}^{2+}(1 \mathrm{~mm}), \mathrm{Co}^{2+}(1 \mathrm{~mm})$ and $\mathrm{Zn}^{2+}(1$ $\mathrm{mm})$ on D-glucose isomerization to D-fructose were tested in this study. The results are shown in Fig. 3. The results showed that the presence of divalent metal ions $\mathrm{Cu}^{2+}, \mathrm{Ca}^{2+}$, and $\mathrm{Zn}^{2+}$ was not conducive to the isomerization of $\mathrm{D}$ glucose to produce D-fructose. The divalent $\mathrm{Cu}^{2+}, \mathrm{Ca}^{2+}$, and $\mathrm{Zn}^{2+}$ exerted the inhibition effect on the activity of GI, so it was not conducive to the synthesis of D-fructose. The presence of bivalent metal ions $\mathrm{Ba}^{2+}, \mathrm{Fe}^{2+}, \mathrm{Mg}^{2+}, \mathrm{Mn}^{2+,}$ and $\mathrm{Co}^{2+}$ promoted the synthesis of $\mathrm{D}$-fructose, especially the presence of $\mathrm{Mg}^{2+}$ and $\mathrm{Co}^{2+}$, which made the D-fructose content reach $4.95 \mathrm{~g} / \mathrm{L}$ and $2.96 \mathrm{~g} / \mathrm{L}$ respectively, 4.85 and 2.9 times of the control $(1.02 \mathrm{~g} / \mathrm{L})$. 


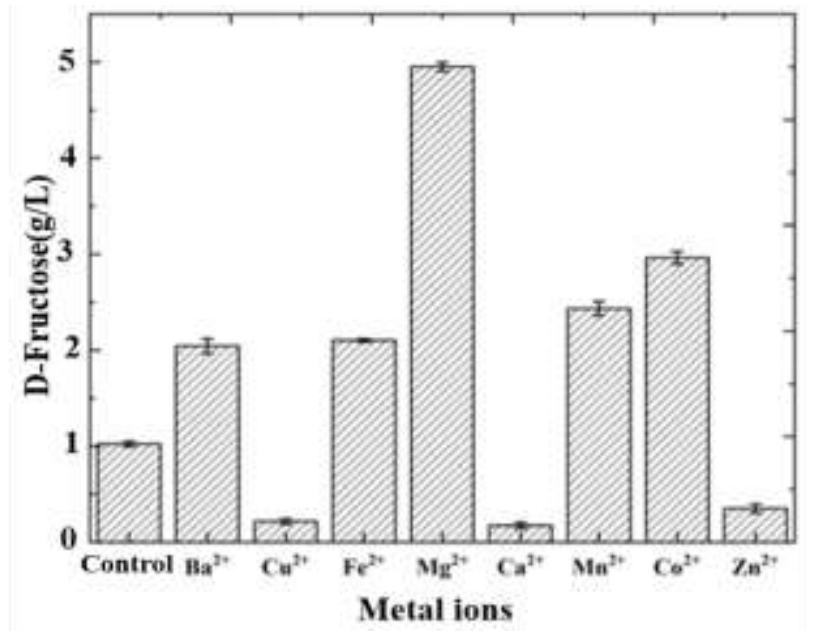

Fig. 4 The effect of divalent cations on the biotransformati on of D-glucose into D-fructose

\subsubsection{EFFECT OF SUBSTRATE D-GLUCOSE CONCENTRATION ON THE BIOTRANSFORMATION OF D-GLUCOSE TO D-FRUCTOSE}

An appropriate increase of substrate concentration can accelerate the reaction rate, which is conducive to product synthesis. It can be seen from Fig.5 that the D-fructose content increases with the increase of D-glucose concentration when the substrate $\mathrm{D}$-glucose concentration is in the range of $0 \sim 1.0 \mathrm{~mol} / \mathrm{L}$. when the substrate Dglucose concentration is $1.0 \mathrm{~mol} / \mathrm{L}$, the D-fructose content reaches the highest, $27 \mathrm{~g} \mathrm{/} \mathrm{L.} \mathrm{When} \mathrm{the}$ concentration of substrate was higher than $1.0 \mathrm{~mol} / \mathrm{L}$, the concentration of D-glucose increased, but the content of D-fructose decreased. It may be that if the concentration of D-glucose exceeded a certain value, the activity of the GI enzyme would be inhibited, which was not conducive to the isomerization of glucose to D-fructose. Therefore, the content of D-fructose decreased.

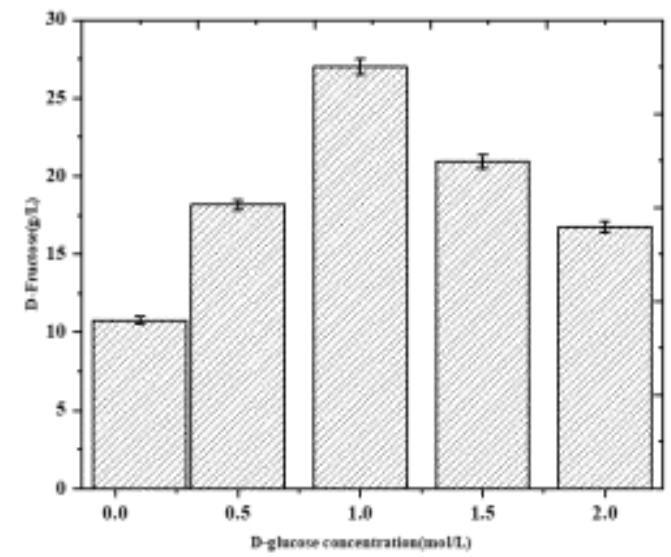

Fig. 5 The effect of substrate D-glucose concentration on $D$-glucose biotransformation to D-fructose

\subsubsection{EFFECT OF PH ON BIOTRANSFORMATION OF D-GLUCOSE TO D-FRUCTOSE}

In the process of isomerization of $\mathrm{D}$-glucose to D-fructose, the optimal $\mathrm{pH}$ is generally $7.0 \sim 9.0$, and $\mathrm{pH}$ has a significant effect on the biotransformation rate of Dfructose. A few GI have good catalytic activity in weak acid $\mathrm{pH}$ environments, while isomerization under weak acid conditions can reduce the formation of by-products [35],35]. It can be seen from Fig. 6 that the GI from codon-optimized A. missouriensis CICIM B0118 (a) in this study is at a high level in the range of $\mathrm{pH} 7.0 \sim 9.0$, reaching $44.83 \mathrm{~g} / \mathrm{L}, 48.10 \mathrm{~g} / \mathrm{L}$, and $46.56 \mathrm{~g} \mathrm{/} \mathrm{L}$, respectively. However, under acidic $\mathrm{pH} 4.0 \sim 6.0$ and peralkaline $\mathrm{pH} 10.0$, the content of D-fructose was not high, which was not conducive to the isomerization of Dglucose to D-fructose.

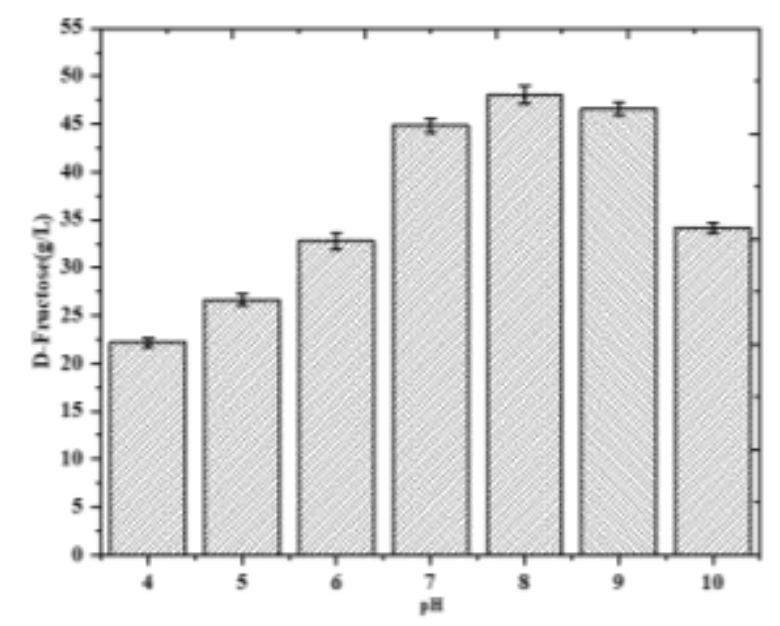

Fig. 6 The effect of pH on D-glucose biotransformation to D-fructose

\subsubsection{EFFECT OF REACTION TEMPERATURE ON BIO-TRANSFORMATION OF D-GLUCOSE TO D- FRUCTOSE}

Previous studies have shown that the isomerization of Dglucose catalyzed by GI is a thermodynamic equilibrium reaction. With the increase of temperature, the catalytic equilibrium moves towards the formation of D-fructose, and high temperature is conducive to the formation of Dfructose $[1,10]$ Therefore, this study also studied the reaction temperature of the whole-cell catalytic system for $\mathrm{D}$-glucose isomerization to D-fructose, and the results are shown in Fig.7. It can be seen from the figure that GI from A. missouriensis CICIM B0118 (a) can tolerate a wide range of temperatures $70{ }^{\circ} \mathrm{C}$ is the optimal temperature for biotransformation. At this time, the $\mathrm{D}$-fructose content is $50.34 \mathrm{~g} / \mathrm{L}$; at $90{ }^{\circ} \mathrm{C}$, the D-fructose content is still at a high level, $36.23 \mathrm{~g} / \mathrm{L}$, only $16.22 \%$ lower than the 
optimal temperature. Due to the rapid decrease of enzyme activity at $80{ }^{\circ} \mathrm{C}$ in Sweetzyme ${ }^{\circledR}$, a commercial enzyme, the content of D-fructose decreased critically. In contrast, GI from A. missouriensis CICIM B0118 (A) has higher catalytic activity at high temperatures, which is beneficial to the industrial production of high fructose syrup.

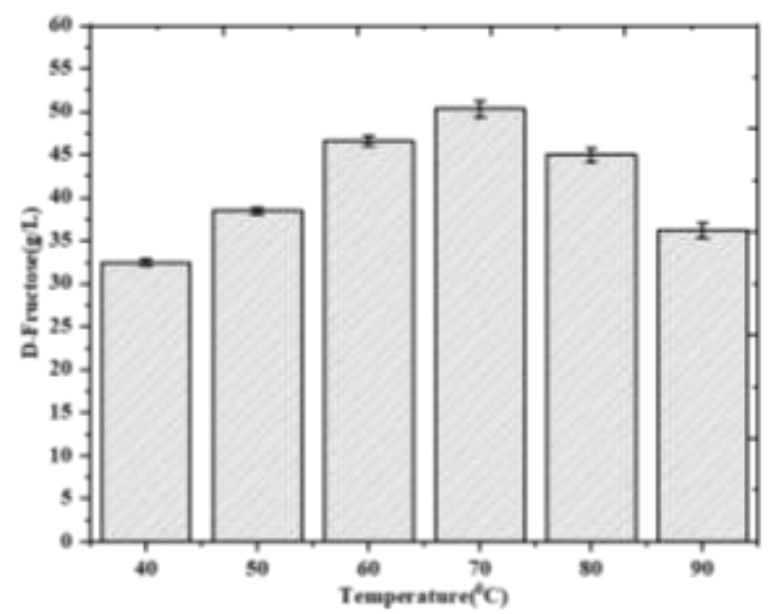

Fig. 7 The effect of reaction temperature on the biotransformation of D-glucose to D-fructose

\subsubsection{WHOLE-CELL CATALYTIC SYNTHESIS OF HIGH FRUCTOSE SYRUP}

Under the optimal transformation conditions, $4 \mathrm{~g}$ DWC were added to $100 \mathrm{ml}$ Tris- $\mathrm{HCl}$ buffer $(\mathrm{pH} \mathrm{7.0)}$ of $180 \mathrm{~g} /$ $\mathrm{L}$ glucose, $10 \mathrm{mmol} / \mathrm{L} \mathrm{Mg}^{2+}$ and $1 \mathrm{mmol} / \mathrm{L} \mathrm{Co}^{2+}$, and transformed at $70^{\circ} \mathrm{C}$ and $220 \mathrm{rpm}$. The supernatant was centrifuged every $3 \mathrm{~h}$, and the content of D-fructose was determined by HPLC. Results as shown in Fig. 8, in the early stage of transformation $(0 \sim 15 \mathrm{~h})$, D-fructose concentration gradually increased with the consumption of substrate D-glucose. At $15 \mathrm{~h}$, the remaining D-glucose concentration in the transformation solution was $71.87 \mathrm{~g} /$ $\mathrm{L}$, D-fructose concentration reached $103.23 \mathrm{~g} / \mathrm{L}$, and the conversion rate was $57.35 \%$. After that, D-glucose consumption slowed down, the reaction basically tended to balance, and D-fructose concentration almost remained constant, $18.5 \% 23 \mathrm{~g} / \mathrm{L}$, D-fructose concentration reached 103. $32 \mathrm{~g} / \mathrm{L}$ and the conversion rate was $57.4 \%$. It can be seen that the recombinant strain B.subtilis 168/ pMA5xylA can safely synthesize HFCS-55 high fructose syrup in one step, which provides an important reference for the sustainable and safe industrial production of HFCS-55 high fructose syrup.

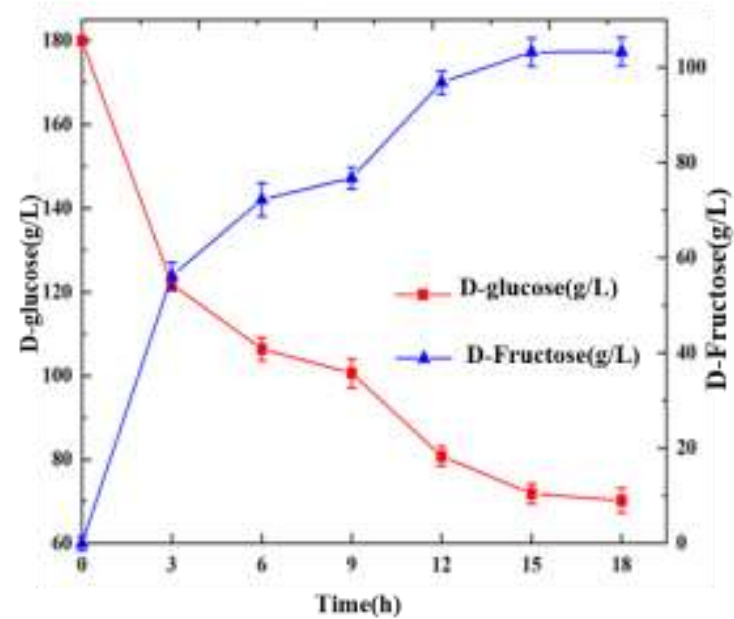

Fig. 8 Whole cells catalyze the isomerization of D-glucose to D-fructose

\section{CONCLUSION}

In this paper, the heterologous expression of GI from $A$. missouriensis CICIM B0118 (A) in food safety bacterial strain Bacillus subtilis 168 was successfully realized for the first time, and the recombinant Bacillus subtilis 168 /pMA5-xylA was constructed to construct the recombinant Bacillus subtilis 168 pMA5-xylA and was used for the whole-cell biocatalysis, the whole-cell transformation conditions (cell concentration, a divalent cation, substrate concentration, $\mathrm{pH}$ and temperature) of D-glucose isomerization to D-fructose were optimized. Under the optimal transformation conditions, the concentration of Dfructose reached $103.32 \mathrm{~g} / \mathrm{L}$ and the conversion rate was $57.4 \%$ for $18 \mathrm{~h}$. One-step safe biosynthesis of HFCS-55 was realized. It is found that GI from A. missouriensis CICIM B0118 (A) has good activity in a wide range of temperatures and $\mathrm{pH}$, respectively $60 \sim 85^{\circ} \mathrm{C}$ and $\mathrm{pH} 7.0$ $\sim$ 9.0, which are suitable for industrial production of HFCS-55 high fructose syrup. The isomerization of Dglucose to D-fructose needs the assistance of divalent metal ions. Divalent metal ions have three functions on GI: activating, stabilizing, and improving the affinity of the Dglucose- GI enzyme. The next step will focus on the effect of divalent metal ions on the biotransformation of Dfructose to realize the sustainable and safe industrial production of high fructose syrup, we should improve the enzyme activity of GI and accelerate the biotransformation rate.

\section{ACKNOWLEDGMENT}

This work was funded by the National Key Research and Development Program of China (2018YFA0900300), the National Natural Science Foundation of China (Grant Nos. 21778024, 31870066,31570085), National First-Class 
Discipline Program of Light Industry Technology and Engineering (Grant No. LITE 2018-06), Fundamental Research Funds for the Central Universities (Grant No. JUSRP51708A), the 111 Project (Grant No. 111-2-06), and the Priority Academic Program Development of Jiangsu Higher Education Institutions.

\section{REFERENCES}

[1] L. Jin, Q. Xu, Z. Liu, Immobilization of Recombinant Glucose Isomerase for Efficient Production of High Fructose Corn Syrup, (2017). https://doi.org/10.1007/s12010-017-2445-0.

[2] R.S. Singh, K. Chauhan, A. Pandey, C. Larroche, Biocatalytic strategies for the production of high fructose syrup from inulin, Bioresour. Technol. (2018). https://doi.org/10.1016/j.biortech.2018.03.127.

[3] K. Sollid, M.S. Edge, A. Bouchoux, A Closer Look at Sugars, 20036

(2012). https://doi.org/10.1097/NT.0b013e3182435de8.

[4] Q. Yang, S. Zhou, T. Runge, Magnetically separable base catalysts for isomerization of glucose to fructose, J. Catal. $330 \quad$ (2015) 474-484. https://doi.org/10.1016/j.jcat.2015.08.008.

[5] R. Van Putten, J.C. Van Der Waal, E. De Jong, C.B. Rasrendra, H.J. Heeres, J.G. De Vries, Hydroxymethylfurfural , A Versatile Platform Chemical Made from Renewable Resources, (2013).

[6] M. Woodley, A. Riisager, T. Sta, Catalysis Science \& Technology Enzymatic isomerization of glucose and xylose in ionic liquids $\mathrm{w}$, (2012) 291-295. https://doi.org/10.1039/c1cy00155h.

[7] C. Liu, J.M. Carraher, J.L. Swedberg, C.R. Herndon, C.N. Fleitman, Selective Base-Catalyzed Isomerization of Glucose to Fructose, (2014).

[8] Q. Yang, M. Sherbahn, T. Runge, Basic Amino Acids as Green Catalysts for Isomerization of Glucose to Fructose in Water,

(2016). https://doi.org/10.1021/acssuschemeng.6b00587.

[9] S. Neifar, F. V Cervantes, A. Bouanane-darenfed, H. Benhlima, A.O. Ballesteros, F.J. Plou, S. Bejar, Immobilization of the glucose isomerase from Caldicoprobacter algeriensis on Sepabeads EC-HA and its efficient application in continuous High Fructose Syrup production using packed bed reactor, Food Chem. (2019) 125710. https://doi.org/10.1016/j.foodchem.2019.125710.

[10] D. Jia, L. Zhou, Y. Zheng, Properties of a novel thermostable glucose isomerase mined from Thermus oshimai and its application to preparation of high fructose corn syrup, Elsevier Inc., n.d. https://doi.org/10.1016/j.enzmictec.2017.01.001.

[11] J.S. White, Sucrose , HFCS , and Fructose: History , Manufacture , Composition , Applications , and Production, (2014). https://doi.org/10.1007/978-1-4899-8077-9.

[12] X. Li, X. Zhang, H. Li, J. Long, Glucose Isomerizes to Fructose Catalyzed by the Eco- Friendly and Biodegradable Ionic Liquids, (2019) 13731-13735. https://doi.org/10.1002/slct.201904192.

[13] C. Li, Y. Wang, Y. Zhang, M. Wang, X. Sun, H. Cui, Isomerization Kinetics of Glucose to Fructose in Aqueous Solution with Magnesium-Aluminum Hydrotalcites, (2020) 270-279. https://doi.org/10.1002/slct.201903959.

[14] I. Delidovich, Recent progress in base-catalyzed isomerization of D-glucose into D-fructose, Curr. Opin. Green Sustain. Chem. $27 \quad$ (2021) 100414. https://doi.org/10.1016/j.cogsc.2020.100414.

[15] Takasaki et al., Enzyma method for converting glucose in glucose syrups to fructose, 1965.

[16] D.-X. Jia, L. Zhou, Y.-G. Zheng, Properties of a novel thermostable glucose isomerase mined from Thermus oshimai and its application to preparation of high fructose corn syrup, Enzyme Microb. Technol. 99 (2017) 1-8. https://doi.org/https://doi.org/10.1016/j.enzmictec.2017.01. 001.

[17] K. Chanitnun, P. Pinphanichakarn, Glucose(xylose) isomerase production by Streptomyces sp. $\mathrm{CH} 7$ grown on agricultural residues, Braz. J. Microbiol. 43 (2012) 10841093. https://doi.org/10.1590/S1517838220120003000035.

[18] S. Givry, F. Duchiron, Optimization of culture medium and growth conditions for production of L-arabinose isomerase and D-xylose isomerase by Lactobacillus bifermentans, Microbiology. $\quad 77 \quad$ (2008) 281-287. https://doi.org/10.1134/S0026261708030053.

[19] Helle Outtrup, Production of glucose isomerase by bacillus coagulans, 1973.

[20] R.K. Bandlish, J.M. Hess, K.L. Epting, C. Vieille, R.M. Kelly, Glucose-to-fructose conversion at high temperatures with xylose (glucose) isomerases from Streptomyces murinus and two hyperthermophilic Thermotoga species, Biotechnol. Bioeng. 80 (2002) 185-194. https://doi.org/10.1002/bit.10362.

[21] R. Di Cosimo, J. Mc Auliffe, A.J. Poulose, G. Bohlmann, Industrial use of immobilized enzymes, Chem. Soc. Rev. 42 (2013) 6437-6474. https://doi.org/10.1039/c3cs35506c.

[22] S. Rehman, H.N. Bhatti, M. Bilal, M. Asgher, Cross-linked enzyme aggregates (CLEAs) of Pencilluim notatum lipase enzyme with improved activity, stability and reusability characteristics, Int. J. Biol. Macromol. 91 (2016) 11611169. https://doi.org/10.1016/j.ijbiomac.2016.06.081.

[23] N. Zhang, X.G. Meng, Y.Y. Wu, H.J. Song, H. Huang, F. Wang, J. Lv, Highly Selective Isomerization of Glucose into Fructose Catalyzed by a Mimic Glucose Isomerase, ChemCatChem. $\quad 11 \quad$ (2019) 2355-2361. https://doi.org/10.1002/cctc.201900143.

[24] Y. Ge, H. Zhou, W. Kong, Y. Tong, S. Wang, W. Li, Immobilization of glucose isomerase and its application in continuous production of high fructose syrup, Appl. Biochem. Biotechnol. - Part A Enzym. Eng. Biotechnol. 69 (1998) 203-215. https://doi.org/10.1007/BF02788814.

[25] S.H. Bhosale, M.B. Rao, V. V Deshpande, Molecular and Industrial Aspects of Glucose Isomerase, 60 (1996) 280300.

[26] C.L. Holmes, M.T. Anderson, H.L.T. Mobley, M.A. Bachman, Pathogenesis of Gram-Negative Bacteremia, 
Clin. Microbiol. Rev. 34 (2021) e00234-20. https://doi.org/10.1128/CMR.00234-20.

[27] M.Q. Carter, A. Pham, S. Huynh, C.T. Parker, A. Miller, X. He, B. Hu, P.S.G. Chain, DNA adenine methylase, not the PstI restriction-modification system, regulates virulence gene expression in Shiga toxin-producing Escherichia coli, $\begin{array}{lllll}\text { Food } & \text { Microbiol. } & 96 & \text { (2021) } & 103722 .\end{array}$ https://doi.org/10.1016/j.fm.2020.103722.

[28] W. Elmonir, S. Shalaan, A. Tahoun, S.F. Mahmoud, E.M.A. Remela, R. Eissa, H. El-Sharkawy, M. Shukry, R.N. Zahran, Prevalence, antimicrobial resistance, and genotyping of Shiga toxin-producing Escherichia coli in foods of cattle origin, diarrheic cattle, and diarrheic humans in Egypt, Gut Pathog. 13 (2021) 1-11. https://doi.org/10.1186/s13099-021-00402-y.

[29] H. Dong, D. Zhang, Current development in genetic engineering strategies of Bacillus species, Microb. Cell Fact. 13 (2014) 1-11. https://doi.org/10.1186/1475-285913-63.

[30] H. Wang, R. Yang, X. Hua, Z. Zhang, W. Zhao, W. Zhang, Expression, enzymatic characterization, and high-level production of glucose isomerase from Actinoplanes missouriensis CICIM B0118(A) in Escherichia coli, Zeitschrift Fur Naturforsch. - Sect. C J. Biosci. 66 (2011) 605-613. https://doi.org/10.1515/znc-2011-11-1210.

[31] A.S. Rozanov, S.N. Zagrebelny, A.B. Beklemishev, Cloning of Escherichia coli K12 Xylose Isomerase ( Glucose Isomerase ) Gene and Studying the Enzymatic Properties, $\quad 45 \quad$ (2009) 38-44. https://doi.org/10.1134/S0003683809010062.

[32] A.J.J. Straathof, S.A. Wahl, K.R. Benjamin, R. Takors, N. Wierckx, H.J. Noorman, Grand Research Challenges for Sustainable Industrial Biotechnology, Trends Biotechnol. $37 \quad$ (n.d.) 1042-1050. https://doi.org/10.1016/j.tibtech.2019.04.002.

[33] L. Fan, Y. Zhang, W. Qu, J. Wang, W. Shao, Cloning and analysis of the xylAB operon and characterization of xylose isomerase from Thermoanaerobacter ethanolicus, Biotechnol. Lett. 33 (2011) 593-598. https://doi.org/10.1007/s10529-010-0463-x.

[34] B. Fatima, M.M. Javed, Production, purification and physicochemical characterization of D-xylose/glucose isomerase from Escherichia coli strain BL21, 3 Biotech. 10 (2020) 1-10. https://doi.org/10.1007/s13205-019-2036-6.

[35] N. Hutadilok-Towatana, A. Painupong, P. Suntinanalert, Purification and characterization of an extracellular protease from alkaliphilic and thermophilic Bacillus sp. PS719, J. Biosci. Bioeng. 87 (1999) 581-587. https://doi.org/10.1016/S1389-1723(99)80118-2.

[36] S.Y. Liu, J. Wiegel, F.C. Gherardini, Purification and cloning of a thermostable xylose (glucose) isomerase with an acidic $\mathrm{pH}$ optimum from Thermoanaerobacterium strain JW/SL-YS 489, J. Bacteriol. 178 (1996) 5938-5945. https://doi.org/10.1128/jb.178.20.5938-5945.1996. 